\title{
The Effectiveness of Problem Based Learning Model With The Assistance of Animation Media on Tetragon Material To The Students Mathematic Learning Achievement of Grade VII SMP Negeri 5 Mandai
}

\author{
A. Muhajir Nasir ${ }^{1 *}$ and Hadijah ${ }^{1}$ \\ ${ }^{1}$ Department of Mathematic Education, Faculty of Teacher Training and Education, Maros Muslim University, Indonesia \\ *Corresponding author: hadijahhaya@gmail.com
}

\section{ARTICLE HISTORY}

Received : 7 January 2019

Revised : 12 February 2019

Accepted : 15 March 2019

KEYWORDS

Problem based learning; Animation media;

Gain normalized

\begin{abstract}
This research was an experimental research that aimmed to know and measure the effectiveness of the application of Problem Based Learning model (PBL) with the assistance of animation media on tetragon material. This research type was quantitative research with one group pretest-posttest design. The population in this study was the students of class VII SMP Negeri 5 Mandai with a random sample of 28 students in an experimental class. Data collection using a test of learning achievement that has been validated by the expert. The data of this research were analyzed descriptively and inferential with normality test as prerequisite analysis test. The results of the data analysis showed that the average pre-test was 45,57 while the average post-test was 84,32 . Average gain scores normalized 0,72 in the high category and normally distributed for learning achievement data. Based on the t-test obtained $0,000<a=$ 0,025 we could conclud that there was a significant increase. The post-test also showed that 26 out of 28 students $(92,86 \%)$ have reached KKM score in mathematics in SMP Negeri 5 Mandai. The results of this study indicate that there was a significant improvement on the mathematics learning achievement of students after being taught with PBL model with the assistance of animation media on tetragon material.
\end{abstract}

This is an open access article under the CC-BY-SA license.

\section{INTRODUCTION}

Education plays a very important role in realizing a generation of potential and quality nation. Education serves to help students develop themselves related to the development of their potential, skills and personal characteristics in a positive direction for themselves and their environment.

Improving the quality of education is an interesting thing to always examine especially mathematics education. In the world of mathematics education needs to be given to all students starting from elementary school to equip students with the ability to think logically, analytically, systematically, critically, and creatively, as well as the ability to cooperate. These competencies are needed so that students can develop into human beings who are qualified and able to answer the challenges of an ever-changing era. One reflection of the quality of education in schools is the learning outcomes of students achieved by meeting the Minimum Completion Criteria (KKM) determined by the school concerned. Thus the learning outcomes of students in a particular subject is one indicator of the quality of education in the school concerned.

In line with developments in education and technology today, it should be able to support the improvement and progress of the quality of education in schools. But in reality, mathematics is a frightening lesson in the midst of increasingly advanced Indonesian education. Various models and learning methods have been used by the teacher to convey the subject matter, but still mathematics is difficult to understand and less attractive to some students. The lack of interest of students in mathematics will affect the success in learning mathematics. This causes the lack of enthusiasm of students to learn, students tend to be quiet and reluctant to raise questions or opinions, so students often experience difficulties and mistakes in solving a mathematical problem, especially in applying mathematical formulas. If this is not considered in the learning process, it can be ascertained that understanding of mathematical concepts will be lacking and lead to low learning achievement which ultimately results in low quality education.

In addition, the low interest of students in mathematics learning can be triggered because of the lack of innovation that is raised in learning, for example by using learning media. As instructors, educators need to create a conducive learning atmosphere for students to learn well, one of them is by utilizing technological developments for the use of appropriate and appropriate learning media in increasing students' interest in 
learning so that they can obtain good learning outcomes.

Based on information from the seventh grade mathematics study teachers in SMP Negeri 5 Mandai, most students still have not achieved mastery learning because they lack an active role in the learning process. Most students are not actively involved in the learning process so they do not understand the material explained. As a result, students are not able to achieve mastery learning. Therefore, there is a need for appropriate learning models and strategies in accordance with the conditions of students to create a conducive learning atmosphere. Educators are required to be able to manage the learning process so that students have the desire to learn.

The conducive learning atmosphere can be achieved by applying a learning model that makes students as the center of learning activities or in other words learners-oriented learning so that students can be active and understand the concepts of the material being taught. One learning model that can be applied to support student-oriented learning is the Problem Based Learning (PBL) model. PBL is an innovation in learning that allows students to optimize their thinking skills through a systematic group work process so that students can empower, sharpen, test, and develop their thinking skills on an ongoing basis (Tan in Rusman, 2013). In addition, Margetson stated that the PBL curriculum helps to improve the development of lifelong learning skills in an open, reflective, critical, and active learning mindset. PBL curriculum facilitates the success of problem solving, communication, group work, and interpersonal skills better than other approaches (Rusman, 2013). Thus, the Problem Based Learning model can be one solution to encourage students to think and work which then triggers the willingness of students to ask questions that have not been understood so that an active and creative learning atmosphere can be formed.

In order for the learning process of mathematics to be meaningful, contextual and not boring learning strategies are needed that can involve students actively and enable students to be able to use the knowledge they have to construct new knowledge. One solution that can be applied is to use learning media in the form of animation media. Learning with animation media aims to arouse the interest of students in learning and facilitate educators in delivering learning material. Based on research conducted by Nasir (2017) learning with animation media is effective in increasing students' interest and learning achievement in mathematics learning. The results showed that the average gain normalized mathematics learning achievement of students was 0.71 , the score was at high criteria. The probability value from the analysis of one sample t-test is 0,000 $<\mathrm{a}=0,050$, meaning that $\mathrm{HO}$ is rejected. From these two things it can be said that the mathematics learning achievement of students after being taught using animation media experienced a high increase.

As a media, animation meets the requirements to be used as learning media. Animation media was chosen because this media has characteristics that are able to arouse the interest of students to learn, which are interesting shapes and colors, trigger the interest of students to learn, and most importantly can clarify the concepts of the material taught to students.

In addition, based on the research conducted by Akmal (2015) regarding the effect of the problem based learning model with the help of computer animation media on the learning process on student learning achievement showed an increase in student learning outcomes which was significant at $81 \%$. Other research on the application of the problem based learning model with the help of animation media in the learning process conducted by Putra (2016) which shows the influence of the application of problem based learning models with the help of animation media with student learning outcomes in the pre-test obtained an average of 43, 50 while the post-test obtained an average of 83.33 which indicates an increase in student achievement after the problem based learning model is applied with the help of animation media in the learning process.

Based on the description above, the authors are motivated to conduct research with the title "The Effectiveness of Problem Based Learning Model with the Assistance of Animation Media on Tetragon Material to the Students Mathematics Learning Achievement of Grade VII SMP Negeri 5 Mandai".

\subsection{Formulation of The Problem}

Based on the above background, the problem statement in this study can be stated as follows: (1) What is the Problem Based Learning model with the help of effective animation media on the learning achievement of Grade VII students of SMP Negeri 5 Mandai on tetragon material? ; (2) How is the effectiveness of the Problem Based Learning model with the help of animation media on the learning achievement of Grade VII students of SMP Negeri 5 Mandai on tetragon material?

\subsection{Research Purposes}

Based on the problem and problem solving formula, the purpose of this study are as follows: (1) To determine the effectiveness of the Problem Based Learning model with the help of animation media on the learning achievements of class VII students of SMP Negeri 5 Mandai; (2) To measure the effectiveness of the Problem Based Learning model with the help of animation media on the learning achievement of Grade VII students of SMP Negeri 5 Mandai.

\subsection{Benefits of Research}

The benefits expected from the results of this study are as follows: (1) For students, learning mathematics using the Problem Based Learning (PBL) model with animation media will be more innovative and fun which gives a positive influence on students' learning interest in mathematics; (2) For educators, the results of this study can be used as consideration in innovating mathematics learning in the classroom so that they can develop their professional skills in teaching; (3) For schools, the results of this study will contribute positively to the progress of the school in order to improve and improve the quality of learning, especially mathematics subjects and generally all subjects in school.

\subsection{Term Limit}

To provide an overview of the problems to be examined, a term limitation is needed to limit the meaning of the terms associated with this research. Some limitations of the terms that need to be explained are as follows: (1) The effectiveness of this research is intended as a success or usefulness of the Problem Based Learning (PBL) model with the help of animation media on student learning achievement. The effectiveness of this learning is indicated by the learning achievement of students taught through PBL models with the help of animation media to achieve learning completeness in accordance with the specified Minimum Completion Criteria (KKM) and significant improvement in learning achievement between pre-test and post-test; (2) Problem Based Learning (PBL) model is a learning 
model that involves students to learn knowledge related to the problem and at the same time have the skills to solve a problem; (3) Animation media is a mathematical learning media that contains a collection of images that are processed in such a way as to produce a movement that impresses life and stores learning messages; (4) Learning achievement is the score obtained by students in the mastery test of teaching materials conducted before and after mathematics learning using the Problem Based Learning (PBL) model with the help of animation media.

\section{RESEARCH METHODS}

\subsection{Type and Design of Research}

This type of research is Pre-experimental with quantitative methods. This study uses treatment on the object of research involving one class group as an experimental class without control variables. The treatment in question is by applying the problem based learning model with animation media.

The design of this study is in the form of One Group Pretest-Posttest Design as presented in the following table:

Table 1. One Group Pretest-Posttest Design

\begin{tabular}{ccc}
\hline Pre Test & Treatment & Post Test \\
\hline T1 & $\mathrm{X}$ & T2 \\
\hline
\end{tabular}

\section{Information:}

T1 : Pre test, test before treatment

T2 : Post test, test after treatment

$\mathrm{X}$ : Problem based learning model with the assistance of animation media

\subsection{Location and Research Time}

The research was conducted in Class VII-A of the Middle School 5 Mandai for the year of 2017/2018 which was located at Jalan Poros Makassar-Maros. The time of the study was carried out in the even semester of the academic year 2017/2018 precisely on April 9 to May 1, 2018.

\subsection{Population And Sample}

Population is a generalization area consisting of objects or subjects that have certain qualities and characteristics determined by researchers to be studied and then conclusions drawn (Sugiyono, 2006). The population in this study were VII grade students of SMP Negeri 5 Mandai.

Samples are partially or representative of the population under study (Arikunto, 2006). The sample in this study was all students of class VII-A SMP Negeri 5 Mandai as many as 28 people with the sampling technique was simple random sampling.

\subsection{Variable and Operational Definitions}

\subsubsection{Research Variable}

Independent variable is an influential variable namely the learning process by applying a problem based learning model with the help of animation media.

Dependent variable is a variable that is influenced or gained influence namely mathematics learning achievement of students of class VII-A SMP 5 Mandai.

\subsubsection{Operational Definitions}

(a) Problem Based Learning (PBL) model is a learning model that involves students actively in solving a problem so that students are able to learn and understand knowledge related to problems given and able to improve intellectual abilities and problem solving abilities of students;

(b) Animation media is a mathematical learning media that contains a collection of images that are processed in such a way as to produce a movement that impresses life and stores learning messages. Media animation is one of the learning media that can be used to counteract the boredom of students when learning so that it triggers learners' motivation and interest in learning;

(c) Learning achievement is a score obtained by students in the mastery test of teaching materials conducted before and after learning mathematics using the Problem Based Learning model with the assistance of animation media

\subsection{Data Collection Technique}

The data sources in this study were students. The type of data obtained is quantitative data taken from the learning achievement test in the form of pre-test and post-test.

The method of retrieval of data in this study is the data on learning achievement taken by giving tests to students before and after learning.

\subsection{Data Analysis Technique}

Data on student achievement is collected through the provision of tests. The test is given twice, namely before the learning process takes place (pre-test) and after the learning process (post-test). The test given is a validated test.

Student learning achievement is directed at learning achievement individually and classically. Criteria for students are said to be thoroughly studied if they have a value of at least 75 , while classical completeness is achieved if at least $75 \%$ of students in the class have achieved a score of at least 75 . The data on student achievement will be analyzed descriptively and inferentially as follows:

\subsubsection{Descriptive Statistics}

Descriptive statistics are used to describe student's learning achievement. In addition, in this study we will describe how differences occur after students are treated. The difference will be reviewed based on the calculation of the normalized gain value. The normalized gain value in this study was obtained by dividing the gain score (difference between posttest and pretest) with the difference between the maximum score and the pretest score. The normalized Gain Value calculation is based on the opinion of Hake (in Nasir, 2013) mathematically with the following formula:

$$
\begin{array}{ll}
\mathrm{G} & =\mathrm{O}_{2}-\mathrm{O}_{1} \\
<\mathrm{g}> & =\frac{\mathrm{O}_{2}-\mathrm{O}_{1}}{\mathrm{SM}-\mathrm{O}_{1}}
\end{array}
$$

The formula is used to calculate normalized gain from differences that occur in students' mathematics learning achievements with the following information:

$\mathrm{G} \quad$ gain (difference)

$<\mathrm{g}>\quad=$ nomalized gain

$\mathrm{O} 1=$ pretest score

$\mathrm{O} 2=$ posttest score

$\mathrm{SM}=$ maximum score 
The normal gain score obtained is interpreted to state the improvement criteria that occur and as variable data to be used in testing the research hypothesis. The reference criteria for gains that have been normalized according to Hake (in Nasir, 2013), are presented in the table below:

Table 2. The Normalized Gain Categories

Interval Categories

$\begin{array}{ll}<\mathrm{g}>\geq 0,70 & \text { High } \\ 0,30<<\mathrm{g}><0,70 & \text { Medium } \\ <\mathrm{g}>\leq 0,30 & \text { Low }\end{array}$

\subsubsection{Inferential Statistics}

Inferential statistics are used to test the research hypothesis. In this study used statistical analysis One Sample T-test to test the research hypothesis. But before hypothesis testing is carried out, a prerequisite test is conducted first. The prerequisite test before testing this hypothesis is to test the normalized normalized gain score of student's mathematics learning achievement data.

Normality test is intended to find out whether the data studied comes from populations that are normally distributed or not. In this study, the normality test used the SPSS 20 application program with the following procedure:

Hypothesis

HO : samples from normal distributed populations

H1 : samples from unusual distibuted populations

a. Test Statistics

A significance level (a) is a number that indicates an analysis error. The significance level in this study is $5 \%$ or 0.05 .

\section{b. Test Decision}

$\mathrm{H}_{0}$ is accepted if the Sig value in the Shapiro-Wilk test is more than the predetermined alpha level ( $p$ value $\geq 0.05$ ).

\section{RESULTS AND DISCUSSIONS}

\subsection{Description of Research Results}

The description of the results of this study describes the learning achievement of students before and after being given treatment in the form of the application of the Problem Based Learning (PBL) model with the assistance of animation media in the experimental class. For more details, it is presented in the following table:

Table 3. Recapitulation of Students Mathematic Learning Achievement Tests

\begin{tabular}{lcc}
\hline & Pre Test & Post Test \\
\hline Number of Samples & 28 & 28 \\
Minimum & 27 & 67 \\
Maximum & 56 & 97 \\
Mean & 45,57 & 84,32 \\
Median & 44 & 85 \\
Range & 29 & 30 \\
Standard Deviation & 6,968 & 6,923 \\
Variance & 48,550 & 47,930 \\
\hline
\end{tabular}

In table 3, it can be seen that the scores on student's the assistance of animation media experience positive changes. This can be seen from the change in the score that occurred at the lowest value from 27 to 67 , the highest value from 56 to 97 , the class average of 45.57 based on the learning achievement criteria is in the low category to 84.32 which is in the high category, and changes in the median value from 44 to 85 .

Based on the description of student's learning achievements above, the mathematics learning achievement of students after being taught using the PBL model with the help of animation media in the experimental class can be said to increase. In other words, the learning achievement of students after being given treatment is different from the learning achievement of students before being given treatment. These differences indicate an increase in mathematics learning achievement of students. As for the learning completeness of students based on the rules that have been set in SMP 5 Mandai in class VII, students are said to be complete on math subjects if they achieve a minimum completeness score of 75 . After students are taught using PBL models assisted by animation media there are 26 of 28 students who can achieve the value of completeness, or in other words the completeness of students' mathematics learning achieved in the experimental class is 92.86\%.

Furthermore, to describe the increase that occurs after students are taught using the PBL model assisted by animation media, researchers have analyzed the normalized gain scores shown in the following table:

Table 4. Normalized Gain of Students Mathematic Learning Achievement

\begin{tabular}{lc}
\hline & Normalized Gain Score \\
\hline Min & 0,54 \\
Max & 0,94 \\
Mean & 0,72 \\
Variance & 0,009 \\
Std. Deviation & 0,09298 \\
\hline
\end{tabular}

Table 4 shows that the normalized gain average of students' mathematics learning achievement is 0,72.. Based on the normalized gain category in table 3.3 shows that the normalized gain average is at high criteria. That is, classically the mathematics learning achievement of students in tetragon material after being taught by applying PBL models assisted by animation media has increased high.

\subsection{Inferential Analysis}

\subsubsection{Results of The Prerequisite Test of Analysis Research Results}

The prerequisite test used in analyzing the results of this study is the normality test, where the normality test is used to find out the data used comes from populations that are normally distributed or not. The normality test of the data used in this study was carried out with the help of the SPSS 20 application program. Data was normally distributed if the p-value in the Shapiro-Wilk test was more than alpha (a).

The computational results are testing the normality of the data, the summary of the results is presented in the table 5 . 
Table 5 Normality Test Results

\begin{tabular}{lc}
\hline Source & Normalized Gain \\
$p$-value & 0,542 \\
$\mathrm{a}$ & 0,05 \\
Decision & $p$-value $>\mathrm{a}$ \\
Conclusion & Normal \\
\hline
\end{tabular}

Based on the results of the above normality test, obtained the p-value (sig) in the Shapiro-Wilk test of more than 0.05 so that it can be concluded that the data in this study came from populations that were normally distributed.

\subsubsection{Results of Hypothesis Testing}

Hypothesis testing in this study used one sample t-test on normalized gain data. The t-test in this study was used to determine the increase in mathematics learning achievement of students after the PBL model was applied with the help of animated media on a rectangular flat build material. The computational results of this test are carried out with the help of the SPSS application whose summary results are presented in the following table:

Table 6. One Sample T-Test

\begin{tabular}{ll}
\hline Source & Normalized Gain Mathematics \\
& Learning Achievement \\
$t_{\text {test }}$ & 24,004 \\
$p$-value & 0,000 \\
Decision & Ho rejected \\
\hline
\end{tabular}

HO : There was no significant increas in students mathematic learning achievement after applying problem based learning model with the assistance of animation media

H1 : There was a significant increas in students mathematic learning achievement after applying problem based learning model with the assistance of animation media

\section{The statistical hypothesis is:}

$\mathrm{H}_{0}: \mu_{\overline{\mathrm{g}}} \leq 0,30 \quad$ versus $\mathrm{H}_{1}: \mu_{\overline{\mathrm{g}}}>0,30$

with $\mu_{\bar{g}}=$ Parameter of gain average normalized posttest score and pretest of mathematics learning achievement of students.

Based on the summary of data analysis results in table 6 , the value of tcount $=24.004$ with the $p$-value $=0,000<a=$ 0.025 , according to the decision-making criteria to test the hypothesis can be concluded that $\mathrm{HO}$ is rejected. That is, there is a significant increase in mathematics learning achievement of students after being taught by applying a problem based learning model with the help of animation media in mathematics learning achievement of students.

In table 4 , it can be seen that the normalized gain average parameters post-test and pre-test scores of mathematics learning achievement of students with 0.72 are at high criteria.

\subsection{Discussions}

The application of the Problem Based Learning (PBL) model with the help of animated media has a positive influence on students' mathematics learning achievement. The influence can be explained by the average value of the mathematics learning achievement test that is measured through the initial test (pre-test) before students are given treatment and the final test (post-test) after students are treated. The average value of students in the pre-test was 45.57 then the average value increased to 84.32 in the post-test at the end of learning. The post-test also showed that 26 out of 28 students or in other words $92.86 \%$ of students had achieved the minimum completeness criteria (KKM) in mathematics at SMP 5 Mandai, which is 75 . In addition, a significant increase in achievement learners of mathematics learning can also be seen through the parameters of normalized gain average scores of mathematics learning achievement of students reaching 0.72 with high criteria, where gain scores are normalized mathematics learning achievements of students are distributed on medium and high criteria. This shows a significant increase in mathematics learning achievement of students in a tetragon material after being taught by applying PBL models assisted by animation media.

Learning with PBL models assisted by animation media on tetragon material aims to facilitate educators in teaching and make it easier for students to understand the material. With the help of animation media students will get a real picture so that the process of receiving students to learning material will be more meaningful. In addition, when applied to learning students are more interested and enthusiastic about learning, even actively asking questions and expressing opinions and knowledge they have learned in class..

The more positive thing is that students show good learning achievement. This can be seen when active students answer and do the exercises given in front of the class. Students also show an in-depth understanding of the concept of a tetragon with the ability to explain well in front of the class.

This is in accordance with the opinion of Akmal (2015) in his research regarding the effect of the problem based learning model with the help of computer animation media in the learning process on student learning achievement which showed an increase in student learning achievement which was significant at $81 \%$. In addition, based on research conducted by Nasir (2017) learning with animation media is effective in increasing student's interest and learning achievement in mathematics learning. The results showed that the average gain normalized mathematics learning achievement of students was 0.71 , the score was at high criteria. The probability value from the analysis of one sample t-test is $0,000<\mathrm{a}=0,050$, meaning that $\mathrm{H}_{0}$ is rejected. From these two things it can be said that the mathematics learning achievement of students after being taught using animation media experienced a high increase.

Based on the description above it can be concluded that learning by applying a problem based learning model with the help of animation media in class VII of SMP 5 Mandai can improve students' mathematics learning achievement.

\section{CONCLUSION}

Based on the results of the analysis and discussion that has been done, the researcher draws some conclusions as follows:

1. The average pre-test score of 45.57 increased to 84.32 in the average post-test score. The probability value from the analysis of one sample t-test is $0,000<a=0,025$ so that 
there is a significant increase in student's mathematics learning achievement after being taught by applying the problem based learning model with the assistance of animation media.

2. Learning of problem based learning models with the assistance of effective animation media to be applied tetragon material in class VII of SMP. This is based on the following things:

a. $92.86 \%$ of students achieve classical learning completeness

b. The average normalized gain of students' mathematics learning achievement is 0.72 in the high category.

Based on the these two things, it can be said that the mathematics learning achievement of students in tetragon material after being taught using the animation media-based problem based learning model has increased significantly.

\section{Suggestions}

Based on the above conclusions in this study, the researchers put forward some suggestions as follows: (1) It is expected that problem based learning models with the help of animation media can be applied in learning to improve student's mathematics learning achievements; (2) It is hoped that this kind of research will also be carried out on other mathematics material and subject matter as well as on other subjects to improve student learning achievement both at the level of junior high school (SMP) and at the high school level (SMA); and (3) It is expected that future researchers who are interested in developing this research or conducting further research in order to examine the limitations of this study so that further research can improve the results of this study.

\section{REFERENCES}

Abdillah, Pius dan Danu Prasetya. (2010). Kamus Besar Bahasa Indonesia. Surabaya: Arkola.

Akmal, Maulidatul. (2015). Pengaruh Model Pembelajaran Problem Based Learning (PBL) Dengan Bantuan Media Animasi Komputer dan LKS Terhadap Hasil Belajar Kimia Siswa Pada Materi Sistem Koloid. Skripsi tidak dipublikasikan. Medan: Program Sarjana Universitas Negeri Medan.

Arifin, Zainal. (1990). Evaluasi Instruksional (Prinsip-Teknik-Prosedur). Bandung: Remaja Rosdakarya.

Arikunto, Suharsimi. 2006. Dasar-Dasar Evaluasi Pendidikan. Jakarta: Bumi Aksara.

Djamarah, Syaiful Bahri. (2006). Strategi Belajar Mengajar. Jakarta: Rineka Cipta.

Kurniasari, Chatarina Etty. (2010). Keefektifan Pembelajaran Matematika Dengan Model Problem Based Learning Berbantuan CD Interaktif Materi Persegi Panjang Dan Persegi Kelas VII SMPN 1 Limpung Batang. Skripsi tidak dipublikasikan. Semarang: Program Sarjana Universitas Negeri Semarang.

Nasir, A. Muhajir. (2013). Penerapan Media Animasi Pada Materi Bangun Datar Segi Empat Dalam Pembelajaran Matematika Kelas VII SMP. Thesis. Pasca Sarjana Universitas Negeri Makassar.

Nasir, A. Muhajir. (2016). Statistik Pendidikan. Yogyakarta: Media Akademi.

Nasir, A. Muhajir. (2017). Pengembangan Perangkat Pembelajaran Model Pengajaran Langsung yang
Melibatkan Media Animasi. Jurnal Kompetensi (Jurnal Ilmiah Ilmu Pendidikan), Volume 11, Nomor 1, hal. 110.

Putra, Ramadhansyah. (2016). Pengaruh Penggunaan Media Animasi Pada Model Pembelajaran Problem Based Learning (PBL) Terhadap Hasil Belajar Siswa Kelas X Pada Materi Reaksi Redoks. Skripsi tidak dipublikasikan. Medan: Program Sarjana Universitas Negeri Medan.

Qurohman, M. T. (2015). Pengembangan Perangkat Model Pembelajaran Somatic Auditory Vizulalisation Intellectualy berbasis Realistic Mathematic Education untuk Meningkatkan Kemampuan Pemecahan Masalah Materi Program Linier (Doctoral dissertation, Universitas Terbuka).

Rusman. (2013). Model-Model Pembelajaran (Mengembangkan Profesionalisme Guru). Edisi Kedua. Jakarta: Rajagrafindo Persada.

Sadiman, Arief S. (2010). Media Pendidikan (Pengertian, Pengembangan, dan Pemanfaatannya). Surabaya: Rajawali Pers.

Sugiyono. (2006). Statistika Untuk Penelitian. Bandung: Penerbit Alfabeta.

Suprihatiningrum, Jamil. (2016). Strategi Pembelajaran (Teori dan Aplikasi). Yogyakarta: Ar-ruzz Media.

Winkel, W.S. (2009). Psikologi Pengajaran. Yogyakarta: Media Abadi. 